\title{
EKONOMI KREATIF, UPAYA MENGINGKATKAN EKONOMI DALAM PEMANFAATAN BUAH MENGKUDU MENJADI KOPI BERKHASIAT DITENGAH PANDEMI COVID-19
}

\author{
Tb. Dedy Fuady \\ Sistem Informasi, Universitas Banten Jaya, Jl. Syech Nawawi Albantani Serang Banten \\ Email: Tb.dedifuadi@unbaja.ac.id
}

\begin{abstract}
The University of Banten Jaya (UNBAJA) Student Work Lecture Program (KKM) in 2020, amidst the prolonged Covid-19 Pandemic and has an impact on the Decrease in the Economic Sector of the Community, so this program aims to improve the skills and creativity of the community, especially Serang City in Perumahan Ciujung Damai, Kec. Kragilan, Kab. Serang, in particular. Housewives in utilizing plant products that may not be considered to have a Selling Value, namely noni fruit or in Latin (noni). The method of implementing this program is by: 1. Field observations, interviews regarding regional economic potential, 2. Providing training on how to use noni fruit to process coffee with other flavors, 3. Conduct training in the marketing aspect by making attractive packaging. The result of this activity is the use of this efficacious noni coffee fruit can improve the community's economy, and can preserve plants that we rarely encounter. With this program, it is hoped that Perumahan Ciujung Damai, Kec. Kragilan, $K a b$. Serang can improve their skills and creativity and increase income in the economic sector amid the COVID-19 epidemic and can also provide eco-tourism areas.
\end{abstract}

Keywords: Noni; Coffee; Efficacy.

\begin{abstract}
ABSTRAK
Pogram Kuliah Kerja Mahasiswa (KKM) Universitas Banten Jaya (UNBAJA) tahun 2020, ditengah Pandemi Covid-19 yang berepanjangan dan bedampak pada Penurunan Pendapatan Sektor Eonomi masyarakat, sehingga program ini bertujuan bagaimana meningkatkan keterampila dan kreatifitas masyarakat khususnya di Perumahan Ciujung Damai, Kec. Kragilan, Kab. Serang, khususnya para Ibu ibu Rumah tangga dalam memafaatkan hasil tanaman yang boleh dipandang belum memiliki Nilai Jual yaitu buah mengkudu atau dalam bahasa latin (noni). Metode Pelaksanan Program ini adalah dengan melakkan: 1. Pengamatan lapangan, wawacara mengenai Potensi ekonomi daerah; 2. Memberikan pelatihan mengenai cara pemanfaatan buah mengkudu menjadi olahan Kopi yang bercitarasa lain; 3. Melakukan peltihan dalam aspek pemasaran dengan membuat kemasan yang menarik. Hasil dari kegiatan ini adalah pemanfaatan buah kopi mengkudu Berkhasiat ini dapat meningkatkan ekonomi masyarakat, serta dapat melestarikan tanaman yang sudah jarang kita jumpai. Dengan adanya program ini diharapkan Masyarakat Perumahan Ciujung Damai, Kec. Kragilan, Kab. Serang dapat meningkatkan keterampilan dan kratifitasnya serta menigkatkan Pendapatan di sekor ekonomi ditengahpandemi COVID-19 dan juga dapat dijaikan daerah eco wisata.
\end{abstract}

Kata Kunci: Mengkudu; Kopi; Khasiat.

\section{PENDAHULUAN}

Mengkudu yang dalam bahasa latinnya Morinda citrifolia (noni) adalah tumbuhan untuk obat -obatan yang banyak sekali tumbuh di Indonesia tepatnya di Kepulauan Maluku dan sekitarnya. Mengkudu berasal dari wilayah daratan Asia Tenggara dan kemudian menyebar sampai ke Cina, India, Filipina, Hawaii, Tahiti, Afrika, Austra-lia, Karibia, Haiti, Fiji, Florida dan Kuba. Pada tahun 100 SM, penduduk Asia Tenggara bermigrasi dan mendarat di kepulauan 
Polinesia, mereka hanya membawa tanaman dan hewan yang dianggap penting untuk hidup di tempat baru. Tanaman-tanaman tersebut memiliki banyak kegunaan, antara lain untuk bahan pakaian, bangunan, jajanan dan obat-obatan,

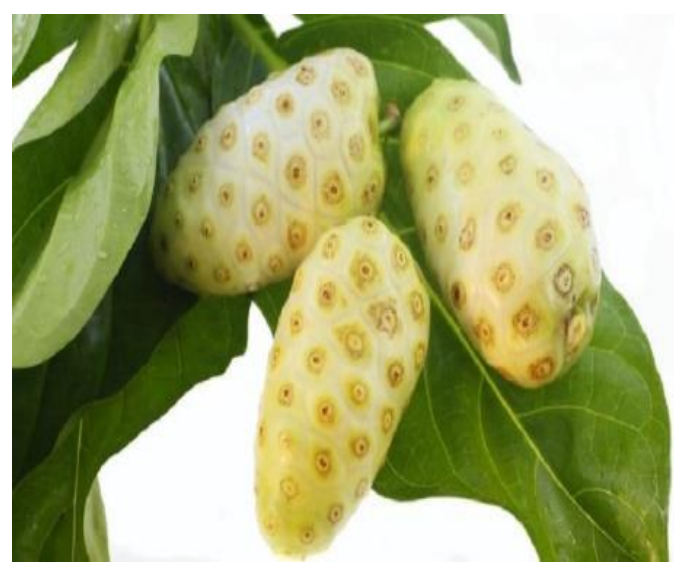

\section{Gambar 1. Buah Mengkudu}

Mengkudu tergolong dalam famili Rubiaceae. Nama lain untuk tanaman ini adalah Noni (bahasa Hawaii), Nono (bahasa Tahiti), Nonu (bahasa Tonga), ungcoikan (bahasa Myanmar) dan Ach (bahasa Hindi). Tanaman ini tumbuh di dataran rendah hingga pada ketinggian $1500 \mathrm{~m}$. Tinggi pohon mengkudu mencapai 3-8 m, memiliki bunga bongkol berwarna putih. Buahnya merupakan buah majemuk, yang masih muda berwarna hijau mengkilap dan memiliki totoltotol dan ketika sudah tua berwarna putih dengan bintik-bintik hitam (Djauhariya et al. 2006).

Mengkudu sejak zaman dahulu sebenarnya telah dikenal dan banyak dipergunakan sebagai bahan sayuran atau pengobatan, namun kemudian tersisih dengan kemajuan zaman. Beberapa publikasi menyatakan bahwa buah mengkudu berkhasiat untuk mengobati aterosklerosis, diabetes, tekanan darah tinggi, radang tenggorokan, batuk, serta mencegah penyerapan lemak dan melancarkan air seni. Selama ini buah mengkudu hanya dijadikan jus dan kurang diminati warga, padahal, buah mengkudu juga dapat diolah menjadi produk menyerupai kopi.

\section{Kandungan Mengkudu}

Mengkudu atau Noni memiliki banyak zat aktif yang sangat berkhasiat dalam mencegah dan mengatasi berbagai penyakit. Berikut adalah kandungan senyawa berkhasiat yang terdapat dalam mengkudu menurut wikipedia:

a) Senyawa Terpenoid

Senyawa terpenoid adalah senyawa hidrokarbon isometrik yang juga terdapat pada lemak atau minyak esensial (essential oils), yaitu sejenis lemak yang sangat penting bagi tubuh. 
Zat-zat terpenoid membantu tubuh dalam proses sintesa organik dan pemulihan sel-sel tubuh (Solomon 1999).

b) Zat Anti-bakteri

Acubin, Asperuloside, Alizarin dan beberapa zat Antraquinon telah terbukti sebagai zat anti bakteri. Zat-zat yang terdapat di dalam buah mengkudu telah terbukti menunjukkan kekuatan melawan golongan bakteri infeksi: Pseudonmonas aeruginosa, Proteus morganii, Staphylococcus aureus, Bacillus subtilis dan Escherichia coli (Waha 2000; Winarti 2005). Zat anti-bakteri dalam buah mengkudu dapat mengontrol dua golongan bakteri yang mematikan (patogen), yaitu Salmonella dan Shigella. Penemuan zat- zat anti bakteri dalam sari buah mengkudu mendukung kegunaannya untuk merawat penyakit infeksi kulit, pilek, demam dan berbagai masalah kesehatan yang disebabkan oleh bakteri (Winarti 2005).

c) Beberapa Jenis Asam

Asam askorbat yang ada di dalam buah mengkudu adalah sumber vitamin $\mathrm{C}$ yang luar biasa. Vitamin C merupakan salah satu antioksidan yang hebat. Antioksidan bermanfaat untuk menetralisir radikal bebas (partikel-partikel berbahaya yang terbentuk sebagai hasil sampingan proses metabolisme yang dapat merusak materi genetik dan merusak sistem kekebalan tubuh). Asam kaproat, asam kaprilat dan asam kaprik termasuk golongan asam lemak. Asam kaproat dan asam kaprik inilah yang menyebabkan bau busuk yang tajam pada buah mengkudu (Winarti 2005).

d) Scopoletin

Pada tahun 1993, peneliti universitas Hawaii berhasil memisahkan zat-zat scopoletin dari buah mengkudu. Zat-zat scopoletin ini mempunyai khasiat pengobatan dan para ahli percaya bahwa scopoletin adalah salah satu di antara zat-zat yang terdapat dalam buah mengkudu yang dapat mengikat serotonin, salah satu zat kimiawi penting di dalam tubuh manusia (Waha 2000). Scopoletin berfungsi memperlebar saluran pembuluh darah yang mengalami penyempitan dan melancarkan peredaran darah. Selain itu scopoletin juga telah terbukti dapat membunuh beberapa tipe bakteri, bersifat fungisida (pembunuh jamur) terhadap Pythium sp. dan juga bersifat anti-peradangan dan anti-alergi (Heinicke 2001 dalam Nuryati 2003).

e) Xeronine dan Proxeronine

Salah satu alkaloid penting yang terdapat dalam buah mengkudu adalah xeronine. Xeronine dihasilkan juga oleh tubuh manusia dalam jumlah terbatas yang berfungsi untuk mengaktifkan enzim-enzim dan mengatur fungsi protein di dalam sel. Xeronine ditemukan pertama kali oleh Dr. Ralph Heinicke (ahli biokimia). Walaupun buah mengkudu hanya mengandung sedikit xeronine, tetapi mengandung bahan-bahan pembentuk (prekursor) 
xeronine, yaitu proxeronine dalam jumlah besar (Solomon 1999). Proxeronine adalah sejenis asam koloid yang tidak mengandung gula, asam amino atau asam nukleat seperti koloidkoloid lainnya dengan bobot molekul relatif besar, lebih dari 16.000. Apabila mengkonsumsi proxeronine maka kadar xeronine di dalam tubuh akan meningkat. Di dalam tubuh manusia (usus) enzim proxeronase dan zat-zat lain akan mengubah proxeronine menjadi xeronine. Fungsi utama xeronine adalah mengatur bentuk dan rigiditas (kekerasan) protein-protein spesifik yang terdapat di dalam sel. Hal ini penting mengingat bila protein-protein tersebut berfungsi abnormal maka tubuh akan mengalami gangguan kesehatan (Heinicke 2001 dalam Nuryati 2003).

\section{Kopi}

Kopi merupakan salah satu jenis tanaman perkebunan yang sudah lama dipegolahan kan dan memiliki nilai ekonomis yang lumayan tinggi. Kopi berasal dari Afrika, yaitu daerah pegunungan di Etopia. Namun, kopi sendiri baru dikenal oleh masyarakat dunia setelah tanaman tersebut dikembangkan di luar daerah asalnya, yaitu Yaman di bagian selatan Arab (Hamni,2013).

Dalam rangka pemanfaatan buah mengkudu, diolah menjadi teh noni dan kopi mengkudu sebagai ramuan untuk mendukung percepatan kesembuhan suatu penyakit yang telah dirangsang dengan pijat repleksi. Pengertian dari teh noni dan kopi mengkudu, bukan berarti gabungan buah mengkudu dengan daun teh, atau dengan buah kopi, namun yang dimaksud adalah olahan buah mengkudu yang dikeringkan sehingga dibentuk menjadi seperti teh (semi serbuk) dan menjadi bubuk/serbuk seperti kopi.

Menurut Sjabana dan Bahalwan (2002), buah mengkudu mengandung sederetan antioksidan diantaranya scopoletin, nitric oxide, vitamin C (asam askorbat), dan vitamin A ( $\beta$ karoten). Ditambahkan oleh Casimir dan David (1998), scopoletin merupakan suatu senyawa fenol yang memiliki aktifitas antioksidan. Selain senyawa-senyawa tersebut Bangun dan Sarwono (2002), menyebutkan bahwa dalam buah mengkudu terdapat silenium yang merupakan salah satu mineral dalam mengkudu dan merupakan antioksidan yang hebat. Sedangkan pada kayu manis, menurut Purseglove et al. (1991) terdapat eugenol dan kaumarin dari golongan polifenol yang memiliki aktivitas antioksidan.

Dari hasil pemaparan diatas dari banyak sekali manfaat maupun khasiat mengkudu (noni), akan tetapi masyarakat belum banyak mengetahuinya, sehingga dapat dijadikan sebagai sumber pendapatan bagi petani sehingga dapat meningkatkan pendapatan masyarakat. Selain dapat meningkatkan jumlah pendapatan masyarakat, tanaman mengkudu (noni) ini relatif lebih 
mudah dalam penanaman maupun perawatannya dan didaerah kragilan Kabupaten Serang tanaman ini kerap dijadikan tanaman pekarangan rumah ata tanaan liar.

Berdasarkan hasil survey yang dilakukan melalui pengamatan dan wawancara kepada masyarakat di desa Ciujung kecamatan Kragilan Kabupaten Serang, belum ada masyarakat yang memiliki usaha pemanfaatan mengkudu (noni) menjadi komoditas usaha terutama Kopi mengkudu. Usaha Kopi Mengkudu ini belum banyak dikenal oleh masyarakat Kecamatan Kragilan Kabupaten Srang. Dengan demikian, peluang usaha Kopi Mengkudu ini sangat besar untuk diterapkan di Kragilan Kabupaten Serang.

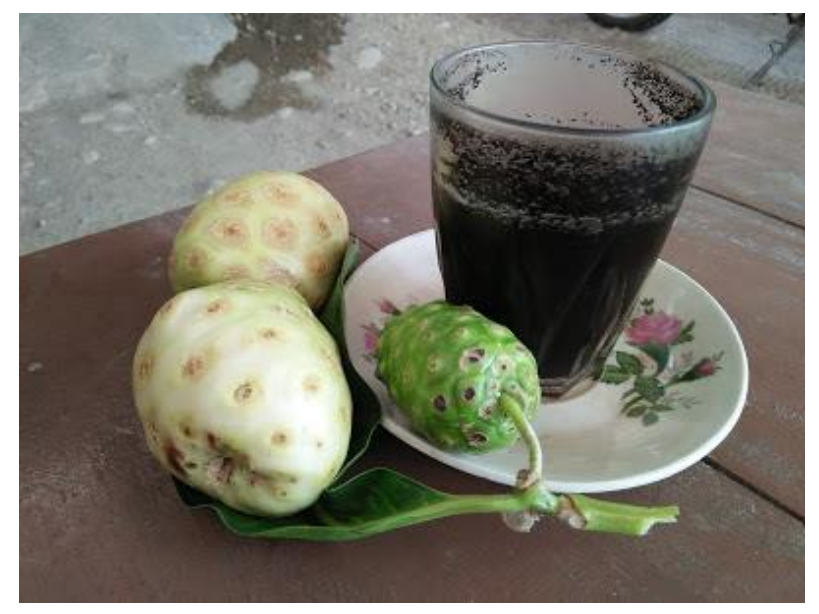

Gambar 2. Kopi Mengkudu

Berdasarkan hal tersebut, maka dalam program pengabdian ini akan memberikan pelatihan dan pembinaan terkait pegolahan Kopi Mengkudu sebagai upaya meningkatkan pendapatan masyarakat Kelurahan Ciujung Kecamatan Kragilan. Adapun bentuk pelatihan dan pembinaan pegolahan kopi Mengkudu ini berupa pemberian pengetahuan dan pemahaman terkait analisa peluang usaha, teknik dan proses pegolahan. Kopi Mengkudu sekaligus memberikan pendampingan pada saat praktek pegolahan kopi mengkudu (noni) serta pengemasan. kegiatan ini hanya berlangsun selama \pm 1 bulan

\section{METODE}

Metode yang dlakukan pada pengabdian ini diantaranya sebagai berikut:

1. Observasi

Metode yang digunakan dalam kegiatan ini adalah (1) pembekalan terhadap mahasiswa KKM Kelompok 11 Universitas Banten Jaya (UNBAJA) yang dilaksanakan di Kampus 1 UNBAJA Jl. Raa Ciwaru Warung pojok kotaSerang dengan memperhatikan protokol Kesehatan.; (2) pelaksanaan pengabdian di Perumahan Ciujung Damai, Kec. Kragilan, 
Kab. Serang. diawali dengan pemberian materi mengenai memanfaatkan Potensi daerah baik berupa Perkebunan,tanaman buah yang hasilnya masih kuang dalam hal pemanaatan secara ekonomis, wisata daerah dll; (3) pelaksanaan dilakukan pada tanggal 09Agustus - 16 Agustus 2020 tersebut di rumah salah satu warga dikarenakan kondisi pandemi Covid-19; (4) Demonstrasi pembuatan Kopi Mengkudu Berkhasiat dengan melakukan uji coba hingga 3 kali untuk mendapatkan rasa yang baik dan enak bagi responden, (5) Praktek pembuatan takakura dengan bimbingan Tim KKM-PPM dan mahasiswa pendamping.

2. Studi Pustaka

Setelah mahasiswa mengetahui atau menentukan jenis produk apa yang akan dibuat, selanjutnya mahasiswa melakukan pembelajaran yang lebih lanjut mengenai produk tersebut yang berhubungan dengan bahan, cara pembuatan, dan juga parameter mutu produk. Studi pustaka dapat diperoleh melalui buku-buku yang ada di perpustakaan atau melalui sarana komunikasi yang lain, misalnya internet.

3. Percobaan

Membuat produk dengan formula yang sesuai dengan selera konsumen, oleh karena itu dilakukan percobaan dengan cara beberapa formula.

\section{HASIL DAN PEMBAHASAN}

Alat, Bahan dan Cara Pembuatan

Alat-alat yang digunakan dalam proses pembuatan "Kopi Mengkudu" adalah sebagai berikut:

1. Pisau

2. Baskom

3. Cabinet Dryer/Oven

4. Loyang

5. Blender

6. Wajan

7. Kompor

8. LPG

9. Ayakan

10. Timbangan 
ISSN : 2686-6447

Bahan-bahan yang digunakan untik proses pembuatan "Kopi Mengkudu" adalah sebagai berikut:

1. Buah Mengkudu (Morinda Citrifolia L./ Noni)

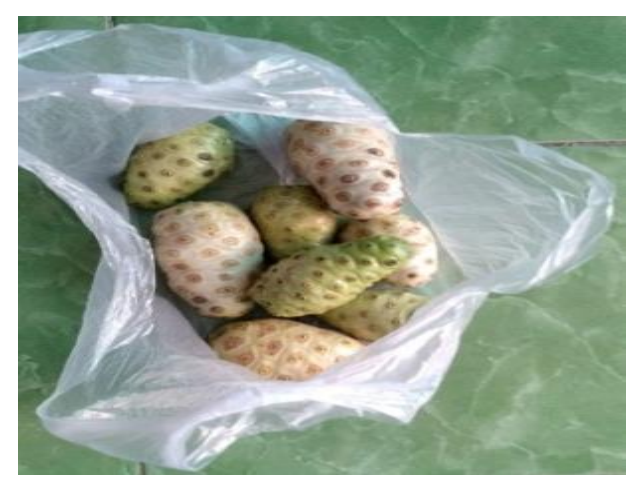

Gambar 3. Buah Mengkudu

2. Kayu Manis

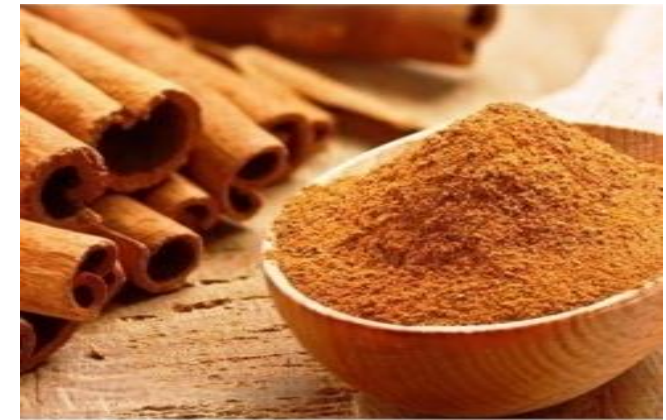

Gambar 4. Kayu Manis

3. Gula Pasir/Gula Aren

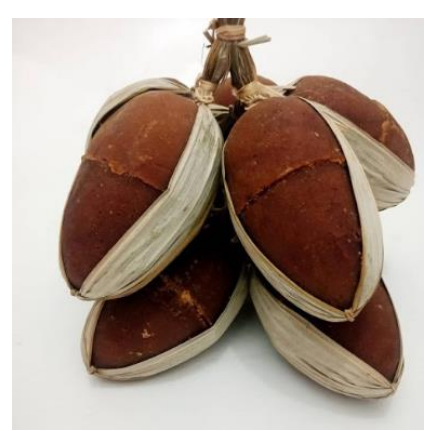

Gambar 5. Gula Aren

4. Daun pandan 
Berikut ini adalah diagram alur cara pembuatan kopi mengkudu berkhasiat

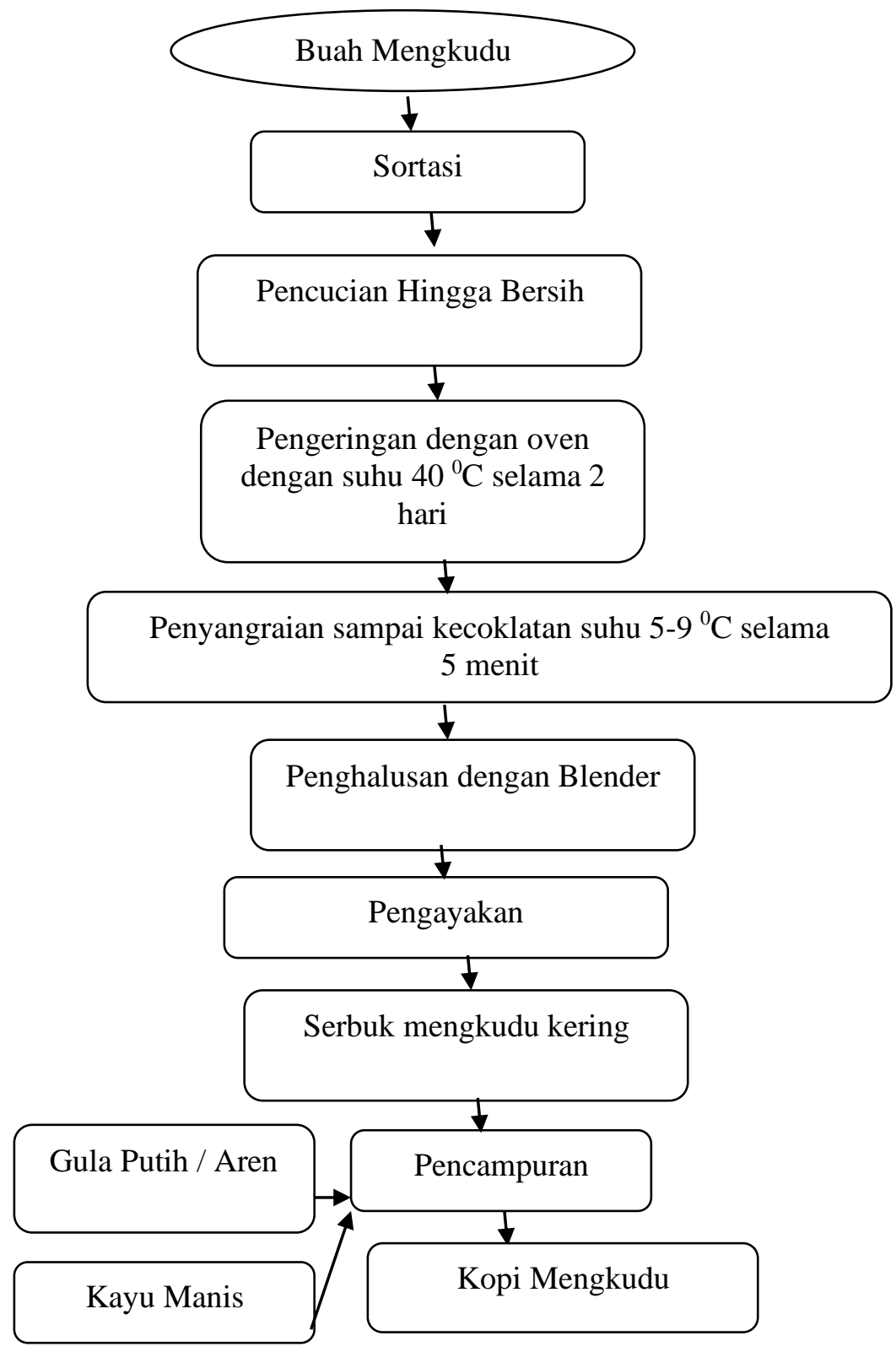

\section{Diagram 1. Cara Pembuatan Kopi Mengkudu}

Dalam mengolah kopi mengkudu, buah mengkudu yang dipakai adalah mengkudu setengah matang, berwarna hijau keputihan, belum berbau, dan tidak busuk. Kulit beserta daging buah mengkudu disayat terlebih dahulu agar terpisahkan dari biji beserta daging yang melekat pada bijinya kemudian dibersihkan. Sayatan yang telah bersih dipanaskan pada suhu $40^{\circ} \mathrm{C}$ hingga kering kemudian disangrai agar menghasilkan warna kecoklatan selanjutnya dihaluskan menjadi bubuk lalu diayak. 
Ayakan bubuk mengkudu yang telah lolos 80 mesh siap dicampur dengan bahan- bahan lainnya. Proses pengolahan kopi mengkudu melalui beberapa tahap antara lain sortasi, pengeringan, penyangraian, pengecilan produk, pengayakan, dan pencampuran.

\section{Uji Coba Rasa Kopi Mengkudu}

Uji coba kopi mengkdu dilakukan dengan 3 ujicoba kepada 20 responden penikmat kopi hitam sebagai berikut :

1. Ujicoba 1: 0,5 gr kopi mengkudu dengan 1,5 gr Gula pasir.

2. Uji coba $2: 0,5$ gr Kopi mengkudu dengan 1,5gr gula pasir dan 0,2 gr bubuk kayu manis.

3. Uji coba 3: 0,5 gr Kopi mengkudu dengan 1,5gr gula pasir dan 0,2 gr bubuk kayu manis,serta air rebusan daun pandan.
S : Suka
C : Cukup
KS : Kurang Suka

Tabel 1. Tabel Uji Coba Responden

\begin{tabular}{|c|c|c|c|c|}
\hline No & Uji Coba & S & C & KS \\
\hline 1 & 1 & 3 & 6 & 11 \\
\hline 2 & 2 & 8 & 10 & 2 \\
\hline 3 & 3 & 12 & 8 & 0 \\
\hline
\end{tabular}

Untuk uji coba 1 kopi didapat bahwa 3 orang suka terhadap kopi mengkudu atau $15 \%$, cukup 6 orang $30 \%$ dan 11 orang kurang suka akan aroma kopi aau $55 \%$ dikarenakan aroma mengkudu masih dominan. Untuk ujicoba ke 2,didapat bahwa 2 orang kurag suka akan mengkudu dan kayu manis, dan sekitar 18 orang suka akan kopi dicampur dengan bubuk kayu manis, dikarenakan aroma mengkudu sedikit hilang akan tetapi efek dan khasiat masih tetap ada.

Untuk uji oba 3, mayoritas orang atau 20 responden sangat suka akan kopi mengkudu ditambah bubuk kayu manis dan air seduan daun pandan. Untuk memiliki rasa kopi yang pas dengan komposisi serbuk kopi 0,5 gram, gula pasir 1,5 gram, dan kayu manis 0,2 gram. Dan seduan air daun pandan, Warna kopi mengkudu dipengaruhi proses pengeringan dan penyangraian. Rasa kopi mengkudu dipengaruhi oleh komposisi gula pasir. Aroma kopi dipengaruhi oleh aroma kayu manis. Cita rasa kopi dipengaruhi oleh serbuk kopi 


\section{Manfaat Kopi Mengkdu}

Diantaranya untuk mengobati penyakit arthritis, diabetes, tekanan darah tinggi (hipertensi), sakit kepala, penyakit jantung, ulkus lambung, arteriosklerosis, dan masalah pembuluh darah, Antitumor dan antikanker. Efek antitumor dan antikankerdiketahui dari hasil penelitian American Association for Cancer Researchyang mengemukakan bahwa endapan alkohol dari buah mengkudu telah meningkatkan hingga $75 \%$ kehidupan tikus dengan kanker Lewis paru dibandingkan dengan tikus kontrol.

\section{Efek Samping}

Efek samping yang ditimbulkan responden akan berbeda-beda tergantung daya tahan tubuh terhadap respon dari luar diantarnya:

1. Badan akan merasakan berkeringat

2. Sering buang air kecil dan besar

3. Badan terasa ringan.

Bentuk pengemasan dan testimony masyarakat

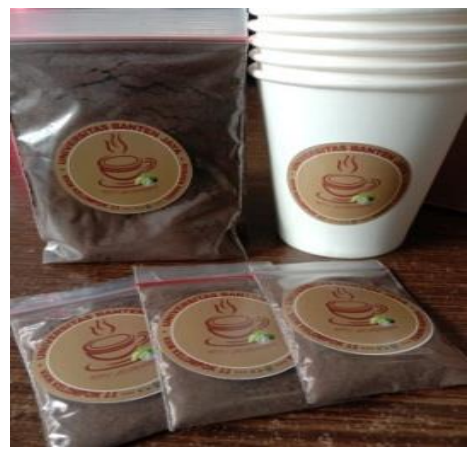

Gambar 6. Noni Coffee

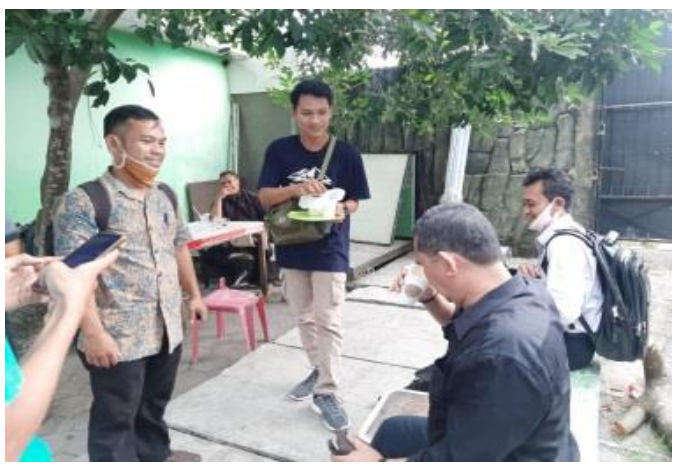

Gambar 7. Testimoni Masyarakat 


\section{KESIMPULAN}

Berdasarkan hasil dan pembahasan dapat diambil kesimpulan sebagai berikut:

1. Kopi mengkudu bukan berarti mengkudu disubstitusi dengan biji kopi tetapi buah mengkudu yang diproses sama seperti proses pembuatan kopi bubuk. Proses pembuatan meliputi sortasi, pengeringan, penyangraian, penghalusan, pengayakan, dam pengemasan.

2. Berdasarkan analisa rangking yang dilakukan, panelisa banyak yang menyukai komposisi serbuk kopi 0,5 gram, gula pasir 1,5 gram, dan kayu manis 0,2 gram. Diambah dengan air seduan daun pandan yang memberikan aroma lain yan menyegarkan. Warna kopi mengkudu dipengaruhi proses pengeringan dan penyangraian. Rasa kopi mengkudu dipengaruhi oleh komposisi gula pasir. Aroma kopi dipengaruhi oleh aroma kayu manis. Cita rasa kopi dipengaruhi oleh serbuk kopi.

\section{DAFTAR PUSTAKA}

Ayanblu, F. at al. (2006). Antithrombotic effect of Morinda citrifolia (Noni) fruit juice on the jugular vein thrombosis induced by ferric chloride in male adult SD rats. Arteriosclerosis Thrombosis and Vascular Biology.

Balitbangkes. (2006). Operational study an integrated community- based intervention program on common risk factors of major non-communicable diseases in Depok-Indonesia. Jakarta: Depkes RI.

Bangun, A. P \& Sarwono, B. (2004). Khasiat dan Manfaat Mengkudu. Jakarta: Agro Media Pustaka.

Departemen Kesehatan. (2004). Survei Kesehatan Nasional. Jakarta: Laporan. Departemen Kesehatan RI.

Djauhariya, E. (2003). Mengkudu sebagai Tanaman Obat Potensial. Balai Penelitian Tanaman Rempah dan Obat. Pengembangan Teknologi TRO, 15(1), 1-16.

Mansjoer, A. (1999). Hipertensi di Indonesia. Jakarta: Media Aesculapius.

Kuncahyo, B. H. (2003). Pengaruh Ekstrak Buah Mengkudu (Morinda citrifolia) Terhadap Kontraksi Otot Polos Aorta Terpisah Marmut (Cavia porcellus) Berendotel yang Distimuli Fenilefrin. [Skripsi]. Malang: Fakultas Kedokteran Universitas Brawijaya.

Mathivanan, N. et al. (2005). Review on the current scenario of Noni research: Taxonomy, distribution, chemistry, medicinal and therapeutic values of Morinda citrifolia. International Journal of Noni Research, 1(1).

Utaminingsih \& Wahyu, R. (2009). Mengenaldan Mencegah Penyakit Diabetes, Hipertensi, Jantung dan Stroke. Yogyakarta: Media Ilmu. 
ISSN : 2686-6447

Jurnal ABDIKARYA

E-ISSN : 2715-6605

Volume 2, No. 2, Oktober 2020

Wang, M. Y. et al. (2002). Morinada citrifolia (noni): a literature review and recent advances in Noni research. Acta Pharmacologica Sinica, 23(12): 1127- 41. 